\title{
More Than a Functional Group: Diversity within the Legume-Rhizobia Mutualism and Its Relationship with Ecosystem Function
}

\author{
Benton N. Taylor ${ }^{1, *(\mathbb{D}}$, Ellen L. Simms ${ }^{2} \mathbb{D}$ and Kimberly J. Komatsu ${ }^{1}$ \\ 1 Smithsonian Environmental Research Center, 647 Contees Wharf Rd., Edgewater, MD 21037, USA; \\ komatsuk@si.edu \\ 2 Department of Integrative Biology, University of California, Berkeley, CA 94720, USA; esimms@berkeley.edu \\ * Correspondence: bentonneiltaylor@gmail.com; Tel.: +01-443-482-2449
}

Received: 31 December 2019; Accepted: 22 January 2020; Published: 28 January 2020

\begin{abstract}
Studies of biodiversity and ecosystem function (BEF) have long focused on the role of nitrogen (N)-fixing legumes as a functional group that occupies a distinct and important niche relative to other plants. Because of their relationship with $\mathrm{N}$-fixing rhizobial bacteria, these legumes access a different pool of $\mathrm{N}$ than other plants and therefore directly contribute to increases in productivity and $\mathrm{N}$-cycling. Despite their recognized importance in the BEF literature, the field has not moved far beyond investigating the presence/absence of the legume functional group in species mixtures. Here, we synthesize existing information on how the diversity (species richness and functional diversity) of both legumes and the rhizobia that they host impact ecosystem functions, such as nitrogen fixation and primary productivity. We also discuss the often-overlooked reciprocal direction of the BEF relationship, whereby ecosystem function can influence legume and rhizobial diversity. We focus on BEF mechanisms of selection, complementarity, facilitation, competitive interference, and dilution effects to explain how diversity in the legume-rhizobia mutualism can have either positive or negative effects on ecosystem function-mechanisms that can operate at scales from rhizobial communities affecting individual legume functions to legume communities affecting landscape-scale ecosystem functions. To fully understand the relationship between biodiversity and ecosystem function, we must incorporate the full diversity of this mutualism and its reciprocal relationship with ecosystem function into our evolving BEF framework.
\end{abstract}

Keywords: Fabaceae; functional diversity; nitrogen fixation; productivity; Rhizobiales; species richness; symbiosis

\section{Introduction}

Since its inception in the 1990's, the field of biodiversity-ecosystem function (BEF) has focused on understanding how the diversity of organisms in an ecosystem influences various functions of that ecosystem, such as primary productivity, water and nutrient cycling, decomposition, and ecosystem stability, among others [1,2]. As the field has developed, several potential mechanisms have been proposed to link the diversity and function of an ecosystem. For example, diversity increases ecosystem function via niche complementarity when more diverse communities contain taxa with complementary resource-acquisition strategies, thereby using environmental resources more efficiently [3-5]. Increasing diversity can also increase the probability of a high-functioning species being present in the community (selection effects) or of multiple species serving the same ecological function, thus increasing the stability of that function (functional redundancy effects) [6]. Together, BEF theory proposes that these mechanisms, among others, can influence the magnitude of an ecosystem function (e.g., total primary 
productivity) $[5,7]$, and can also impact the spatial variability $[8,9]$ and temporal stability of ecosystem functions $[10,11]$, as well as the multi-functionality of the ecosystem $[12,13]$. Central to many of these mechanisms is the fact that ecosystem function depends on both the diversity of organisms and their functional roles. As a consequence, functionally unique or important organisms can disproportionately influence the BEF relationship [14,15].

The symbiosis between many legumes (plants in the family Fabaceae) and their nitrogen (N)-fixing microbial partners (bacteria primarily in the order Rhizobiales, among others) allows these organisms to convert atmospheric $\mathrm{N}_{2}$ gas into bio-available forms, making it one of the most important mutualisms affecting the functioning of terrestrial ecosystems. Endosymbiotic rhizobia, housed in specialized root nodules on the legume host, conduct a process known as symbiotic nitrogen fixation (SNF), in which they convert $\mathrm{N}_{2}$ gas into plant-available ammonia, a portion of which they then transfer to the legume host in exchange for photosynthesized carbohydrates [16-18]. This highly efficient N-fixing symbiosis can bring $>100 \mathrm{~kg} \mathrm{~N} \mathrm{ha}^{-1} \mathrm{yr}^{-1}$ into some ecosystems [19] and represents the largest natural source of $\mathrm{N}$ in the terrestrial biosphere [20], in addition to being a critical component of agricultural production worldwide [21]. Because of this critical ecosystem function and their ability to access a different pool of $\mathrm{N}$ than most other plants (i.e., niche differentiation), legumes and their symbiotic nitrogen-fixing rhizobial partners have long been a focus of BEF studies [2,22]. While it is important to note that the process of $\mathrm{N}$ fixation is carried out exclusively by bacteria, we collectively refer to the legume-rhizobia mutualism as "N fixers" throughout this review for simplicity and to reflect the use of similar terms in the BEF literature. Due to their widespread occurrence, ranging from agricultural systems to herbaceous and forested ecosystems (Figure 1), and their critical role in the BEF relationship, understanding of the role of diversity within $\mathrm{N}$ fixers is needed to move the BEF field forward.

As a group, $\mathrm{N}$ fixers occupy an uncommon resource-acquisition niche [23,24], often exhibit high rates of primary productivity and nutrient cycling [22,25], and are resilient to conditions such as drought [26-28] and disturbance [29,30]. Because of these attributes, $\mathrm{N}$ fixers make important contributions to a wide variety of ecosystem functions, such as primary production and ecosystem $\mathrm{N}$ inputs. $\mathrm{N}$ fixers also represent an extremely diverse mutualism [31-33], which creates the potential for a range of diversity-even within the $\mathrm{N}$-fixer group—in a community. The notably high diversity of $\mathrm{N}$ fixers, combined with the important and often unique functions that members of this group provide, make the legume-rhizobia N-fixing mutualism an important, yet complex, component of the BEF relationship in many terrestrial ecosystems.

Although adding $\mathrm{N}$-fixers to multispecies diversity treatments produces one of the strongest and most consistent effects on ecosystem function in BEF experiments [2,34-36], few studies have examined how increasing the diversity within legumes and/or their rhizobial partners affects ecosystem function [37]. Even fewer studies have assessed the reciprocal effects of ecosystem function on the diversity of legumes and rhizobia. Below, we synthesize the current understanding of how changes in the species and functional diversity of legumes and their rhizobial partners influence terrestrial ecosystem functioning. Although many Rosid I plant species can form N-fixing symbioses [38,39], we limit the scope of this review to the legume-rhizobia symbiosis. We first explore the diversity of both partners in the legume-rhizobia mutualism and how different combinations within this partnership can create additional diversity in a community. This diversity can impact multiple ecosystem functions, which we evaluate at the individual-legume scale, the community scale, and across space and time. We also discuss how various ecosystem functions can feed back to influence $\mathrm{N}$-fixer diversity at multiple levels. In doing so, we aim to develop current conceptual theory on how changes in $\mathrm{N}$-fixer diversity can influence the BEF relationship and identify promising next steps for this research field. 


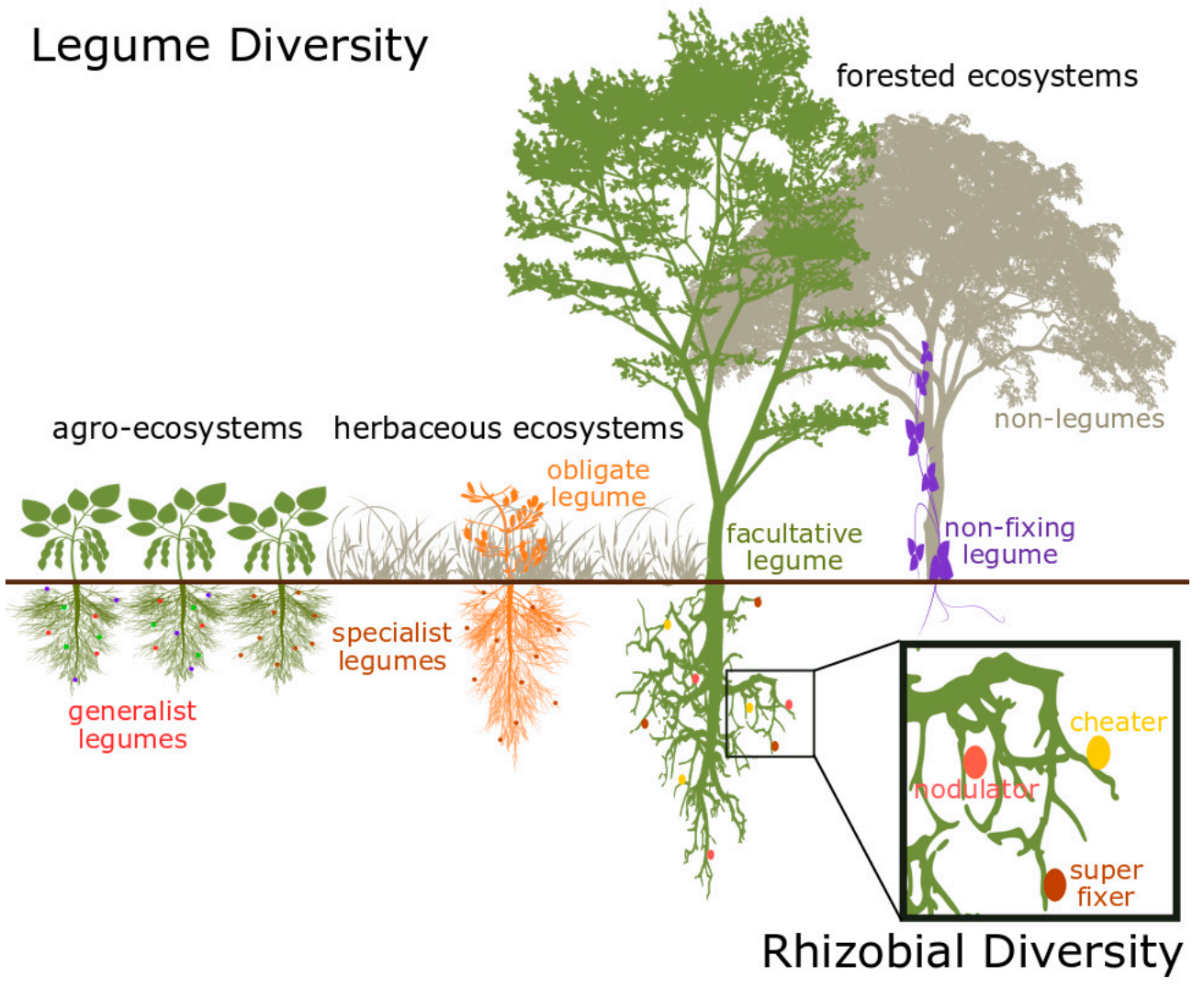

Figure 1. Functional diversity in the legume-rhizobia mutualism. Legumes occupy a variety of habitat types, such as agricultural, herbaceous, and forest ecosystems. They can also take on a range of growth forms (trees, vines, shrubs, and herbs) and substantially differ in their promiscuity with rhizobial partners (generalists vs. specialists) and their ability to regulate symbiotic nitrogen fixation (SNF) (obligate vs. facultative). Belowground, rhizobia are also functionally diverse along axes of habitat type, promiscuity, and partner efficacy (e.g., nodulators, cheaters, super fixers, etc.). This substantial functional diversity can impact the contribution that nitrogen $(\mathrm{N})$ fixers make to ecosystem function through a variety of biodiversity-ecosystem function (BEF) mechanisms.

\section{Diversity in the Legume-Rhizobia Mutualism}

\subsection{Species Diversity}

Understanding the effects of species diversity on ecosystem function in the legume-rhizobia mutualism is inherently complicated by the differing definitions, or species concepts, that are commonly used for organisms on either end of the partnership (Box 1). While traditional species concepts are employed-using either morphological or molecular techniques—-to define legume species, rhizobia are typically grouped into operational taxonomic units (OTUs) using analyses of genetic similarity or into species using a combination of phenotypic and genotypic groupings [40]. Therefore, when discussing rhizobial diversity, we use the term "species" to refer to an OTU, species, or strain, recognizing that how these terms are defined for rhizobia can differ among studies.

Fabaceae is the third most diverse plant family, behind only Orchidaceae and Asteraceae [41], and is comprised of ca. 19,500 species [42], approximately 5500 of which can nodulate and form $\mathrm{N}$-fixing symbioses with rhizobia [33]. N-fixing legume species are unevenly distributed across the three traditional legume subfamilies, with $~ 90 \%$ of Mimosoidieae and Papilionoideae genera, but only $\sim 5 \%$ of Caesalpinioideae genera, having the ability to fix N symbiotically. Interestingly, recent work has argued that the trait of $\mathrm{N}$ fixation itself could serve as a defining characteristic for substantially rearranging legume taxonomy [43]. The persistence of legume diversity in natural communities may be partly due 
to their relationship with rhizobia. Rhizobia obtained from neighboring congener legumes can be more beneficial than those obtained from neighboring conspecifics, creating diminishing benefits of rhizobia shared by conspecific legumes and increasing diversity by promoting rare congeners [44]. Furthermore, legume species often cannot persist in competition with non-legumes in the absence of their rhizobial partners, and the overall plant community evenness is enhanced by rhizobial presence [45].

Box 1. Discrepancy in species concepts for microbes and plants.

A complicating factor when considering the diversity of the legume-rhizobia mutualism is the fundamental difference in species concepts and delineations that are traditionally used for bacteria and plants $[40,46]$. Plants occupy a relatively well-resolved branch of the phylogenetic tree, where the unit of a species is, in general, fairly stable. Although legumes, in particular, are the subject of substantial discussions about species groupings within tribes, subfamilies, and genera [47], what delineates a legume species remains relatively consistent. What determines a bacterial species, however, is substantially complicated by the lack of sexual reproduction, the propensity for horizontal gene transfer, and the relatively recent methodological developments allowing for microbial species identification. Most rhizobial species are delineated based on shared lineages of a "core" genome, allowing for variation in "accessory" genes among individuals within a species [48,49]. However, the rhizobial genes responsible for important functions, such as nodulation (nod) and $\mathrm{N}$ fixation (nif and fix), are accessory genes that are often located on horizontally transmitted "symbiotic islands". This means that, for rhizobia, two individuals of the same species can exhibit very different ecological functions, or conversely, two individuals of even distantly related species can exhibit very similar ecological functions [50]. Therefore, it is important to bear in mind that experiments assessing the effects of rhizobial diversity on legume function are inherently focused on the genetic diversity within rhizobia (as that is the basis for bacterial species delineation), but that the genetic delineation of rhizobial species may not be a reliable indicator of ecological function.

The diversity of legume hosts represents only one side of the N-fixer symbiosis. Rhizobial bacteria currently make up a diverse paraphyletic group of more than 200 species, the majority of which are contained in the alpha-proteobacteria order Rhizobiales (comprised of seven families, including Bradyrhizobiaceae, Phyllobacteriaceae, and Rhizobiaceae) and the beta-proteobacterial family Burkholderiaceae [40,43,51,52], where it is now thought that nodulation first evolved [53]. These rhizobia vary enormously in terms of their genome structure and standing population genetic variation [54-56]. As with legumes, rhizobial diversity may be maintained in natural systems through negative frequency dependence, with legumes selectively partnering with rarer rhizobia [57].

While each partner in the legume-rhizobia mutualism exhibits notable taxonomic diversity, the varying degrees of partner specialization exhibited by both legumes and rhizobia can produce many combinations of $\mathrm{N}$ fixers (i.e., legume and rhizobia pairings), far exceeding the diversity of each group in isolation (Figure 2). If, for example, a community contains five legume species and five rhizobial species, these 10 species could potentially produce 155 different legume-rhizobia combinations (31 possible rhizobial combinations for each of the five legume species) if all five legume species are compatible partners with all five rhizobial species. Indeed, studies have demonstrated that single legume species can partner with at least nine rhizobial species [58-60], that single rhizobial species can partner with multiple genera of legumes [52], and that promiscuity in this mutualism commonly occurs in nature [61]. Although the realized number of partnerships would almost certainly be much lower in nature due to partner specificity, we present this hypothetical example to illustrate that the partnership itself creates the potential for substantial diversity within the legume-rhizobia mutualism that has gone almost entirely unrecognized in the BEF literature. Throughout this review, we use the term "N-fixer diversity" to refer to the full diversity of legume-rhizobia combinations present in a community (bottom tier in Figure 2). 


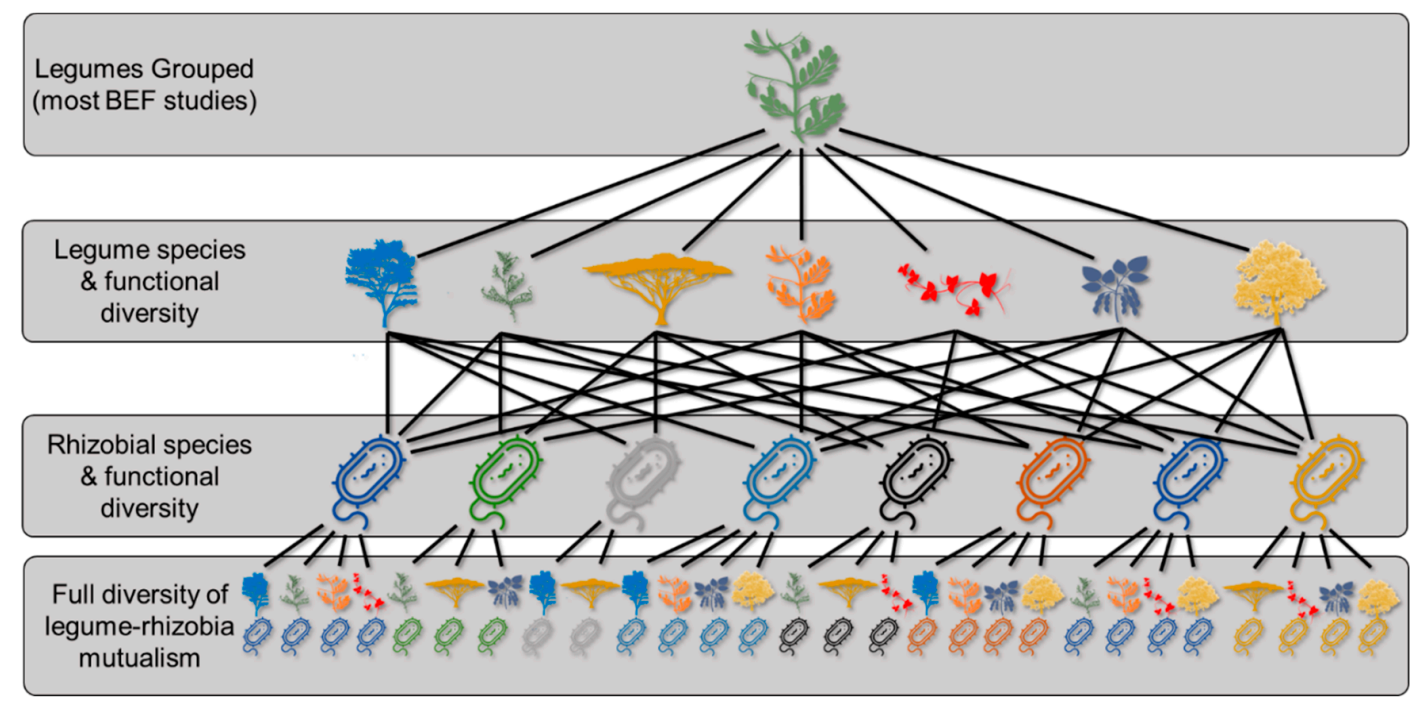

Figure 2. Unseen diversity in the legume-rhizobia mutualism. Studies on BEF relationships have traditionally viewed $\mathrm{N}$ fixers as a single functional group, simply focusing on the presence or absence of $\mathrm{N}$ fixers in a community (top tier). However, in many ecosystems, substantial species and functional diversity exists within the legumes (second tier) and their rhizobial partners (third tier; Figure 1). Because both legumes and rhizobia can be promiscuous in terms of the species with which they partner, the number of combinations of legume-rhizobia mutualisms that can exist in an ecosystem far exceeds the diversity of either partner group on its own (bottom tier). In nature, the effect of promiscuity on legume-rhizobia diversity is likely even greater than depicted here, given that individual legume plants can often partner with multiple rhizobial species at the same time. Accounting for this substantial diversity within the legume-rhizobia mutualism may be critical to fully understanding how N fixers influence BEF relationships.

\subsection{Functional Diversity}

The relationship between functional diversity and ecosystem function has a deep connection with $\mathrm{N}$-fixing legumes, largely because researchers have typically defined these $\mathrm{N}$ fixers as a single functional group; one that tends to have large impacts on several ecosystem functions (as discussed above). Most previous BEF work defines the difference between $\mathrm{N}$-fixers and non-fixers as a component of functional diversity $[22,35,62]$. However, categorizing functional diversity in this way obscures important diversity within functional groups, such as that observed within each partner of the legume-rhizobia mutualism. As we describe below, there is substantial diversity in the function of individual species within both legumes and rhizobia, and each group's functional diversity can have unique effects on ecosystem function.

Legume species differentiate along multiple axes of functional diversity-including growth form, habitat, N-fixation strategy, and partner promiscuity (Figure 1) - each of which can have important impacts on ecosystem function. Legumes are one of the most widespread plant groups on Earth, occupying almost every terrestrial biome, from lowland tropical rainforests to arctic and alpine ecosystems [41,43]. As a result, legumes occur across a wide variety of environmental conditions that can directly or indirectly affect the functions that legumes provide to the ecosystem. These environmental conditions include the availability of soil $N$ [63,64], light [65,66], water [67-69], and other soil nutrients such as phosphorus [64,70]. Legumes also comprise many different growth forms, including vines, herbs, shrubs, and canopy trees [41,71]. This variation means that BEF models must account for the ecosystem functions performed by legumes in the relevant environmental conditions and ecological niches.

Two axes of functional diversity that are unique to $\mathrm{N}$ fixers may play particularly important roles in the ecosystem functions that $\mathrm{N}$ fixers provide. First is variation in the degree to which different 
species of $\mathrm{N}$ fixers can actively regulate $\mathrm{N}$ fixation rates. Once the symbiosis has formed, some $\mathrm{N}$ fixers can regulate how much $\mathrm{N}$ they fix (a facultative $\mathrm{N}$ fixation strategy) through mechanisms such as autoregulation of nodulation [72] or oxygen regulation in the nodule [73], whereas others $\mathrm{N}$ fixers fix $\mathrm{N}$ at constant rates, regardless of environmental conditions (an obligate $\mathrm{N}$ fixation strategy) $[65,74]$. Although the prevailing view for several decades has been that obligate $\mathrm{N}$ fixers are typically non-legume $\mathrm{N}$ fixers (actinorhizal plants that associate with Frankia bacteria) [75], recent evidence suggests that the full range, from obligate to fully facultative $\mathrm{N}$ fixation strategies, exists within $\mathrm{N}$-fixing legumes [63]. Furthermore, within the facultative $\mathrm{N}$ fixers, legume reliance on fixed vs. soil $\mathrm{N}$ varies by species and may depend on plant traits outside of the legume-rhizobia mutualism, such as plant height [76,77].

In addition to how they regulate $\mathrm{N}$ fixation, $\mathrm{N}$ fixers are also functionally diverse in their promiscuity, that is, the phylogenetic breadth of compatible rhizobial partners with which they can form the N-fixing mutualism. While some legume species exhibit strong rhizobial specificity, other legume species partner with multiple rhizobial species, even within a single plant $[58,61,78,79]$. The Jack-of-all-trades hypothesis [80,81] predicts, and empirical evidence supports [82], that generalists (i.e., promiscuous legumes) obtain less average benefit from rhizobia than specialists. Therefore, species-specific legume-rhizobial interactions can directly influence niche and fitness differences among legume species and between legumes and non-legumes, with important consequences for the richness-productivity relationship. Legume species also differ in their ability to enforce cooperation from rhizobial associates through partner choice and sanctioning [83-87]. These axes of functional diversity related to $\mathrm{N}$ fixation indicate that even a single legume species can contribute significant diversity to ecosystem $\mathrm{N}$ cycling.

Like their legume hosts, rhizobia exhibit substantial functional diversity $[88,89]$ despite prolific horizontal gene transfer in functionally important portions of the genome, such as symbiotic plasmids or symbiotic "islands," which can be easily transmitted among closely related core-genome lineages and sometimes move among distantly related rhizobial taxa $[88,90,91]$. Rhizobia can display functional diversity across habitat types, in promiscuity, and in N-fixation strategies. Rhizobia inhabit the soil of almost every terrestrial biome and often exhibit strong biogeographic patterns [92], creating strong potential for legumes to engage in $\mathrm{N}$-fixing symbioses across a wide array of ecosystems and environmental conditions. Rhizobia also exhibit a wide range of promiscuity and a gradient of symbiotic benefits for their host partners [88,92-94]. A single rhizobial species might partner with multiple legumes at a single site [58,82] or across a broad geographic range [95], while other rhizobial species exhibit much narrower host ranges [96]. Rhizobia also vary substantially in their function as symbiotic partners: some rhizobial species are highly effective $\mathrm{N}$-fixers; other species are ineffective "cheaters" of the mutualism; and some species may be effective in some aspects of the mutualism (such as promoting nodule formation), but ineffective in other aspects, such as N fixation (Figure 1) [97].

We have highlighted examples of the ways that, in addition to the notable taxonomic diversity within each group in the legume-rhizobia mutualism, both partners also exhibit a wide range of functional diversity. Below, we describe how this wide array of $\mathrm{N}$-fixer diversity contributes to variation in ecosystem function in unique and important ways.

\section{Diversity's Influence on Ecosystem Function}

Because substantial diversity exists at multiple levels within the legume-rhizobia mutualism, it is important to consider links between diversity and function at each of these levels. Below, we discuss how the diversity of rhizobia influences the function of individual legumes (3.1), how the diversity of the $\mathrm{N}$-fixer mutualism affects the functions of the ecosystems they inhabit (3.2), and how $\mathrm{N}$ fixers affect the variability of ecosystem functions across space and time (3.3). 


\subsection{Individual Legume Function}

The unique and important $\mathrm{N}$-fixing service that rhizobia provide to their legume hosts strongly suggests that changes in the diversity of the local rhizobial community should affect host-plant function. For example, inoculating legumes with rhizobia (i.e., rhizobia presence vs. absence) can increase host plant productivity and tissue $\mathrm{N}$ content $[45,98]$. Beyond these presence/absence effects, higher rhizobial diversity could increase individual legume function through selection, complementarity, and/or facilitation effects. Positive selection effects dictate that a diverse rhizobial community is more likely to contain a particularly effective species $[7,99]$. This selection effect likely applies to many soil rhizobial communities, but no direct tests of this hypothesis currently exist for $\mathrm{N}$ fixers. Rhizobial diversity can also increase legume function through a combination of complementarity and facilitation effects. A more diverse community is more likely to contain a pair of species whose functional traits complement each other in a way that facilitates the functional trait of a third species. For example, the co-occurrence of a highly effective N-fixing rhizobial species with a rhizobial species that excels at initiating nodule formation can increase $\mathrm{N}$ fixation for the host plant [97]. Complementarity/facilitation has been observed in non-legume actinorhizal $\mathrm{N}$-fixing symbioses [100] and likely occurs within legume symbioses, but such positive diversity effects have yet to be demonstrated empirically.

Rhizobial diversity can also decrease host plant function via several mechanisms, including selection, competitive interference, and dilution effects. Negative selection effects could arise because some rhizobia have evolved to "cheat" the symbiosis (Figure 1) by receiving photosynthate without providing fixed N [101,102]. Therefore, increasing rhizobial diversity in the rhizosphere could increase the probability of a cheater (or defective [103]) species infecting the host plant and reducing its productivity. Interference/competition effects might occur if high rhizobial diversity increases interference competition among rhizobial species, which could reduce the community-level function that the rhizobia provide to their legume hosts [97,104]. Additionally, dilution effects dictate that increasing rhizobial diversity could be especially detrimental to a highly specific legume if a diverse soil rhizobial community decreases its likelihood of encountering a compatible rhizobial symbiont. Because the dilution effect is inherently mediated by species interactions, this is an especially important mechanism by which mutualisms could produce a negative BEF relationship. The few experiments that have manipulated rhizobial diversity have found negative relationships between rhizobial diversity and legume productivity [97], citing competitive interference between rhizobial species as the likely mechanism. Although many more studies are needed to gain a broad consensus, this work provides the clearest evidence that rhizobial diversity can have important negative effects on legume function under certain conditions.

Given that $\mathrm{N}$ fixation is the functional trait that sets $\mathrm{N}$-fixing legumes apart, it is surprising that so little work has examined the relationship between rhizobial diversity and legume $\mathrm{N}$ fixation rates. We know of no studies that have assessed the relationship between rhizobial species diversity and $\mathrm{N}$ fixation in natural systems. However, Bala and Giller [105] examined tropical agroforestry legume hosts that can partner with a variety of rhizobia-both effective and ineffective at $\mathrm{N}$ fixation. They found that increasing rhizobial diversity can either increase or decrease per-plant $\mathrm{N}$ fixation, depending on how soil $\mathrm{pH}$ controls rhizobial distributions. The direct effect of rhizobial species diversity on legume-host function, then, likely depends on environmental factors that can vary across multiple scales (Box 2), host specificity, and whether diversity is being assessed outside of the mutualism (i.e., diversity of potential rhizobial symbionts in the soil) or inside the mutualism (i.e., diversity of rhizobia actually partnering with the legume host).

\subsection{Community-Level Ecosystem Function}

The greater likelihood of including legumes as community diversity increases has long been recognized as a dominant effect in BEF experiments-so dominant that early debate questioned if the legume "selection" effect was the only factor driving the BEF relationship [22]. Diversity within the legumes, however, has received little attention in empirical BEF studies. Several mechanisms have been 
proposed to explain how increasing $\mathrm{N}$-fixer diversity increases productivity. Increasing $\mathrm{N}$-fixer diversity could (1) more strongly differentiate the niches of legumes and non-legumes [36,37,62], (2) reduce relative fitness differences between legumes and dominant non-legumes (commonly, C4 grasses in grassland systems) by improving legume competitive ability [45,106,107], and/or (3) more strongly facilitate the growth of non-fixing species by enhancing soil $\mathrm{N}$ via higher $\mathrm{N}$ fixation rates $[36,108,109]$. Despite these general mechanisms that predict how legumes operate as a functional group, legume species vary enormously in how they affect the richness-productivity relationship [110], and one of the most notable gaps in our understanding of the connection between legumes and BEF is the lack of information on how diversity within the legume functional group affects community-scale ecosystem function.

Box 2. Differing scales of diversity for microbes and plants.

The three common scales of diversity in ecology—alpha: diversity within a community; beta: diversity between communities; and gamma: diversity of the regional pool [111]—provide interesting complexity to the relationship between legume-rhizobial diversity and ecosystem function. The massive size difference between the two organisms in the legume-rhizobia mutualism means that larger scales of rhizobial diversity (i.e., beta and gamma diversity) may be nested within smaller scales of legume diversity (i.e., alpha or beta diversity). For example, there may be many distinct communities of rhizobia (rhizobial beta diversity) within a single community of legumes (legume alpha diversity). At larger scales, the entire regional species pool (gamma diversity) of rhizobia may be represented within a single community or a few distinct communities of legumes, while a much larger area is likely necessary to encompass regional legume gamma diversity. These differences in scale can be important when considering the drivers and effects of diversity for each partner in the legume-rhizobia mutualism. Competitive dynamics and selective pressures for rhizobial communities in the soil are driven by environmental variation on the scale of millimeters to meters, whereas environmental drivers of legume competition and selection often vary on scales of meters to kilometers. Therefore, soil properties that are heterogenous at small spatial scales may drive high rhizobial diversity but have relatively little impact on the diversity of the legume community if the roots of an individual legume span the entire range of this heterogeneity. Additionally, the effects of rhizobial alpha and beta diversity can have important effects on scales as small as an individual legume plant or even an individual root nodule, whereas even the local alpha diversity of legumes typically influences ecosystem function on at least the meter scale.

High $\mathrm{N}$-fixer diversity in a community can increase $\mathrm{N}$ fixers' contributions to ecosystem function via either complementarity or selection effects, or both [6]. Because $\mathrm{N}$ fixers occupy a wide range of growth forms and ecological traits (Figure 1) [37], complementarity effects suggest that high N-fixer diversity can increase niche differentiation within the $\mathrm{N}$-fixer community, reducing inter-legume competition for environmental resources such as water, phosphorus, and soil bacteria. Strong evidence demonstrates that $\mathrm{N}$ fixers occupy different niche spaces than non-fixers (strengthening community-wide complementarity effects) [26]. However, little work has assessed niche differentiation between sympatric legumes and how this affects their contribution to ecosystem function, and existing evidence is contradictory.

High $\mathrm{N}$-fixer diversity could either increase or decrease ecosystem functions, such as net primary productivity (NPP) or SNF via selection effects. For selection effects to be strong, the species that contributes disproportionately to ecosystem function must become competitively dominant [5]. For this reason, selection effects are often positive because the most commonly assessed ecosystem function, NPP, is closely related to individual plant biomass production, which is often used to measure a species' competitive ability. Indeed, more diverse $\mathrm{N}$-fixer communities have a higher probability of including a particularly productive N-fixing species, which could increase both NPP and SNF. However, because an $\mathrm{N}$ fixer's effectiveness at fixing $\mathrm{N}$ is not necessarily tied to its competitive dominance under all conditions, increasing legume diversity could increase NPP, but decrease total ecosystem SNF, if the most competitively dominant $\mathrm{N}$ fixers are relatively ineffective at SNF. Several studies have shown that the responses of particularly effective $\mathrm{N}$-fixing species to environmental change can largely drive the effect that $\mathrm{N}$ fixers as a group have on ecosystem function [36,112]. This evidence suggests that whether environmental conditions select for productive, super-fixing $\mathrm{N}$ fixers or for unproductive, 
ineffective $\mathrm{N}$ fixers can largely determine the direction in which selection effects influence ecosystem function. Although little empirical evidence exists on how N-fixer diversity influences ecosystem NPP and SNF, one study from tropical dry forests found that sites with more $\mathrm{N}$-fixing species exhibited lower ecosystem-scale SNF than those with a single species of N-fixer [113], but confounding factors related to stand age make it difficult to attribute this effect to legume diversity.

An important consideration when assessing BEF effects of mutualisms such as legumes and rhizobia is the specificity/promiscuity of each partner in the symbiosis. If a species in the mutualism is a generalist (will engage in symbiosis with multiple partner species), then increasing partner diversity can increase its contribution to ecosystem functioning. For example, legumes that share rhizobial partners have greater niche overlap, which could allow facilitation among legumes and explain why legumes sometimes encourage invasion by other legumes $[79,114]$. In contrast, if the species is a specialist (only partners with a narrow range of potential symbionts), then high diversity on the opposite side of the mutualism could reduce the relative abundance of compatible partners via dilution effects. This may be especially important if the dominant legume species overloads the soil bacterial community with its rhizobial partner(s), decreasing the likelihood that sympatric specialist legumes encounter their compatible rhizobia. Indeed, some legumes resist invasion by other legumes [115] and under-yield in polycultures with other legume species [24], suggesting that the cultivation of a favorable community of rhizobial strains by one legume may facilitate its own growth at the expense of other specialized legume species.

Overall, we have surprisingly little empirical evidence about how diversity within the legume-rhizobia mutualism affects the magnitude of community-scale ecosystem functions. Certainly, considerable evidence indicates that adding $\mathrm{N}$ fixers to a community increases several ecosystem functions $[2,22,35]$. While substantial mechanistic theory suggests that increasing N-fixer diversity can positively influence ecosystem functions such as NPP and SNF, much of the empirical evidence actually points to a negative relationship between $\mathrm{N}$-fixer diversity and ecosystem function. Whether $\mathrm{BEF}$ effects of $\mathrm{N}$-fixer diversity are positive or negative likely depends on environmental conditions, the ecosystem function of interest, the functional traits of the $\mathrm{N}$ fixers, and the specificity of each partner in the mutualism.

\subsection{Variation in Function Across Space and Time}

When assessing the functioning of an ecosystem, it is important to consider how the magnitude of a given function varies across space and through time. There is particularly avid debate in the literature about the concepts of spatial heterogeneity and temporal stability of ecosystem function and the BEF mechanisms that influence them [116]—debate that is largely outside the scope of this work. Instead, we discuss these concepts in general terms as they relate to the effect of N-fixer diversity, but point readers to helpful reviews on the complexity of the many aspects of spatial and temporal stability $[116,117]$.

$\mathrm{N}$-fixer diversity may have strong effects on the spatial heterogeneity of ecosystem functions through niche complementarity of either or both partners in the legume-rhizobia mutualism. Legumes occupy an impressive variety of ecological niches, often even within a single site. Therefore, increasing legume diversity might increase the number of niches occupied by legumes, thereby making a relevant ecosystem function such as SNF more spatially homogeneous, even across disparate microclimates. Because the distributions and function of rhizobia are sensitive to environmental conditions [43,105], increasing the rhizobial species diversity may also increase the homogeneity of $\mathrm{N}$-fixer function across spatial variation in factors such as soil temperature, nutrients, and $\mathrm{pH}$. Despite this potential homogenizing effect, $\mathrm{N}$ fixers often cause spatial heterogeneity in some ecosystem functions. For example, because N fixers disproportionally contribute to NPP and N cycling, adding N fixers to a community can cause these functions to become patchily distributed across the landscape as they are aggregated close to individual $\mathrm{N}$ fixers [118]. 
$\mathrm{N}$-fixer diversity affects temporal stability through both complementarity and redundancy, but its effects differ substantially depending on the timescale and magnitude of the temporal variation being considered. One of the hallmark ecological roles of $\mathrm{N}$ fixers is as pioneer species that facilitate ecosystem recovery following large-scale disturbance $[29,119-121]$. This role in the recovery of plant biomass, NPP, and N cycling following major disturbance suggests that $\mathrm{N}$ fixers enhance long-term ecosystem stability. Beyond effects due to the simple presence/absence of $\mathrm{N}$ fixers as a functional group, diversity within the $\mathrm{N}$-fixer group can also enhance the temporal stability of ecosystem functions across successional time. In regenerating forests in Panama, Batterman et al. [29] showed that different species of $\mathrm{N}$ fixers peaked in $\mathrm{N}$ fixation at different points during succession, exhibiting temporal complementarity of SNF in response to changing environmental conditions across successional time.

In ecosystems characterized by constant changes in environmental conditions rather than frequent large-scale disturbances, $\mathrm{N}$-fixer diversity may have a different influence on temporal stability. When such ecosystems contain multiple species within the legume functional group, legume redundancy, coupled with niche diversity along different axes, might make SNF more resilient to the extirpation of individual legume species as environmental conditions change [122]. This argument predicts a positive relationship between $\mathrm{N}$-fixer diversity and temporal stability in these systems. Experimentally, however, the presence of $\mathrm{N}$ fixers in a community makes ecosystem functions less stable in response to environmental change over time. In experimental grasslands in Minnesota, USA, productivity was significantly less stable across 10 years of environmental variability in plots where $\mathrm{N}$ fixers were present [123]. Although the authors did not provide an explanation for this effect, one plausible mechanism is that, in this system, $\mathrm{N}$ fixers disproportionately contribute to ecosystem productivity [22], making total ecosystem productivity especially sensitive to the environmental changes that affect $\mathrm{N}$ fixers when this group is present.

Clearly, the presence and diversity of $\mathrm{N}$ fixers can have important effects on the spatio-temporal stability of ecosystems and their functions. However, whether their presence and diversity increase or decrease ecosystem stability depends on the severity/nature of the disturbance, the functional traits of the $\mathrm{N}$ fixers in the community, and the timescale of interest.

\section{Function's Influence on Diversity}

While the BEF field has thoroughly demonstrated the important effects of biodiversity on the functioning of many ecosystems, documenting the reciprocal nature of this relationship-the effects of ecosystem function on biodiversity-is substantially more challenging. Many of the effects that ecosystem function has on biodiversity may be indirect, mediated by how that function affects other ecosystem attributes, such as variability, which makes these effects difficult to measure. Building experimental evidence for these reciprocal relationships is also hampered by the logistical difficulty of manipulating particular ecosystem functions without creating substantial confounding effects. Although these difficulties apply to assessing function-to-biodiversity relationships in the legume-rhizobia mutualism, solid mechanistic theory and some empirical evidence suggests that the function of ecosystems can influence legume diversity and that the functional traits of individual legumes can impact the diversity of their rhizobial partners.

The relationship between legume-host function and rhizobial functional diversity may provide some of the clearest potential mechanisms for reciprocal effects of function on biodiversity. Because the reproductive fitness of rhizobial symbionts is inherently linked to their legume hosts [124], legume function can play a direct role in the evolutionary selection and diversification of rhizobia. A wide range of theoretical studies have been conducted exploring the adaptive diversification of rhizobia and the benefits they provide to their host based on the functional needs of the legume. In general, these studies have shown that high legume productivity can select for multiple rhizobial species with a range of N-fixation benefit strategies-from highly effective $\mathrm{N}$ fixers to less effective rhizobial cheaters [101]. Because legume host sanctions are a critical assumption in these evolutionary models, the extent to 
which legume function determines the sanctions that the legume places on its rhizobial symbionts should determine the strength of the effects that host-plant function has on rhizobial diversity.

Over evolutionary timescales, the ability to perform the function of $\mathrm{N}$ fixation has likely been an important driver of global $\mathrm{N}$-fixer diversity $[43,125]$. Over ecological timescales and at individual sites, the most likely mechanism through which ecosystem function should affect legume species diversity is through the effect of function on variability. Increases in ecosystem functions such as NPP and SNF increase the potential heterogeneity of vegetation structure and N availability, which could drive important heterogeneity in selection within a community and thereby increase legume diversity. Empirically, the relationship between ecosystem NPP and N-fixer diversity is mixed. N-fixer diversity is relatively high in highly productive tropical forests, suggesting a potential positive effect of ecosystem function on $\mathrm{N}$-fixer diversity. However, the diversity of all Angiosperms is high in these tropical forests, which means that $\mathrm{N}$ fixers actually make up a similar fraction of total Angiosperm species richness in the tropics, temperate, and boreal latitudes [126]. Therefore, while there does seem to be a positive relationship between NPP and N-fixer diversity, this relationship is similar for both $\mathrm{N}$ fixers and non-fixers. There is a great need for manipulative experiments to investigate whether variation in ecosystem function can cause variation in $\mathrm{N}$-fixer diversity.

\section{Next Steps for the Legume-Rhizobia Mutualism in BEF Research}

Our synthesis of the literature provides clear evidence that the complexity of $\mathrm{N}$-fixer effects on ecosystem function has gone largely unexplored in the BEF literature. Here, we suggest examples of potential avenues for future work exploring these effects to better understand how the full suite of legume-rhizobia diversity influences ecosystem function.

One of the clearest gaps in our understanding of $N$ fixers and BEF relationships is the paucity of data on within-N-fixer diversity effects. Using established experimental designs from the BEF literature to experimentally manipulate the species and functional diversity of both legumes and rhizobia to determine the effects on ecosystem functions such as NPP and SNF, among others, is a clear first step in this line of research. Although understanding the diversity effects of the entire suite of legume-rhizobia combinations in a community (accounting for promiscuity in the partnership, Figure 2) represents an important goal, there are substantial logistic obstacles of actively manipulating these combinations in an experimental framework.

In addition to controlled experimental manipulations, much can be gained from observational studies of the relationship between $\mathrm{N}$-fixer diversity and ecosystem function. For example, assessing the relationship between the diversity of legumes and/or rhizobia and the speed of regeneration across compatible chronosequence studies. While confounding edaphic differences between chronosequence studies present challenges for this type of analysis, sufficiently large collaborative datasets of chronosequence studies now exist $[27,127]$ to account for many of these effects statistically. We can also use observational sampling to assess the relationship between $\mathrm{N}$-fixer diversity and SNF. Several studies have already compared local N-fixer abundances to SNF [36,128], which means that data already exist in multiple ecosystems to assess the relationship between $\mathrm{N}$-fixer diversity and ecosystem SNF.

Assessing feedbacks between function and diversity is severely hampered by logistical challenges of manipulating ecosystem function without creating confounding experimental effects. The legume-rhizobia mutualism does, however, provide potential for this type of manipulation to assess the feedback of individual legume function on rhizobial diversity. Several studies have placed $\mathrm{N}$ fixers into air-tight plant chambers and replaced atmospheric $\mathrm{N}_{2}$ with Argon, preventing the $\mathrm{N}$ fixer from engaging in SNF $[73,129,130]$. These studies have focused on different scientific questions, but this method could be used to manipulate host-plant function (SNF) and assess the resulting effects on rhizobial diversity.

Finally, it is important to consider how the relationship between $\mathrm{N}$-fixer diversity and ecosystem function will change as human activity increasingly alters terrestrial ecosystems. Several prominent global change drivers likely have important impacts on the role of $\mathrm{N}$-fixer diversity in ecosystem 
function (Box 3), but we know relatively little about these dynamics. Anthropogenic environmental change may impact the diversity of $\mathrm{N}$-fixers in communities, while $\mathrm{N}$-fixer diversity may also help dictate how ecosystems respond to global change. Given the critical role of N fixers in Earth System Model predictions of global change [131-133], understanding how the diversity of $\mathrm{N}$ fixers will influence these dynamics may provide important insight into these Earth system model predictions.

Box 3. Legume-rhizobia diversity and ecosystem function in a changing world.

Multiple environmental factors can mediate the relationship between $\mathrm{N}$-fixer diversity and ecosystem function, including $\mathrm{CO}_{2}, \mathrm{~N}$ deposition, temperature, and precipitation. Here, we provide a non-exhaustive list of examples related to the effects of anthropogenic changes in these environmental factors on $\mathrm{N}$ fixers at scales from the molecular efficiency of SNF to the competitive dynamics of legumes across a landscape, and how these effects can mediate $\mathrm{N}$-fixers' influence on ecosystem functioning.

$\mathrm{CO}_{2}$ : Within an individual legume, $\mathrm{CO}_{2}$ drives the availability of $\mathrm{C}$ allocated to rhizobial partners and helps determine the terms of material exchange across the legume-rhizobia mutualism [134], and the diversity of rhizobial partners within an individual plant likely changes how these bargaining dynamics play out [97]. Across legumes, experimental evidence suggests that legume species differ dramatically in their growth and N-fixation responses to elevated $\mathrm{CO}_{2}$ and that these responses can be mediated by other environmental factors, such as soil $\mathrm{N}$, phosphorus, and molybdenum availability [77,135].

N Pollution: Legume species vary substantially in their ability to regulate $\mathrm{N}$ fixation in response to soil $\mathrm{N}$ [63], which suggests that increases in $\mathrm{N}$ deposition could create shifts in $\mathrm{N}$-fixer community composition and may drive the competitive exclusion of $\mathrm{N}$ fixers from some ecosystems. Furthermore, rhizobial evolution has been documented under long-term $\mathrm{N}$ fertilization regimes, which resulted in the destabilization of the legume-rhizobia mutualism [136].

Temperature: Increasing temperature (within relevant ambient temperature ranges) increases the enzymatic efficiency of $\mathrm{N}$ fixation [137], and models suggest that the predicted temperature increases for the coming century will make $\mathrm{N}$-fixing legumes more abundant across the United States [138] and have important impacts on N-fixers' contribution to $\mathrm{N}$ and C cycling [132].

Drought: $\mathrm{N}$ fixers are often competitively dominant in arid environments [27,28,67], and models suggest that increasing aridity could favor $\mathrm{N}$ fixers, but that these effects are smaller than the effect of temperature [138].

The environmental factors discussed above are only a subset of the possible global change drivers that could mediate the relationship between $\mathrm{N}$ fixers and BEF. Increases in species introductions, habitat fragmentation, and phosphorus pollution, among others, also likely influence the effect of $\mathrm{N}$-fixer diversity on ecosystem function. Although BEF theory suggests that higher diversities of legumes and rhizobia should make the mutualism more robust to global change drivers, little empirical work has assessed these effects directly. Understanding how global change mediates the effects of $\mathrm{N}$ fixers on ecosystem function will be important for predicting the future role of $\mathrm{N}$ fixers in terrestrial ecosystems that are increasingly dominated by anthropogenic change.

\section{Conclusions}

The most important conclusion that we can draw from the BEF literature on the legume-rhizobia mutualism is that we have currently explored only a fraction of the potential ways that this mutualism can influence the relationship between biodiversity and ecosystem function. To date, work on $\mathrm{N}$ fixers in the context of BEF has been largely confined to understanding how adding this functional group affects NPP. Yet, the potential diversity effects of both mutualistic partners, the multiple scales of diversity for each of these partners, and the additional ecosystem functions that these axes of diversity can influence all point to strong and potentially more complex relationships between the legume-rhizobia mutualism and ecosystem function than the BEF literature currently reflects. Additionally, many $\mathrm{N}$ fixers simultaneously form additional symbioses such as mycorrizal associations [139-142] and ant-plant mutualisms [143-145]—partnerships that further add to N-fixer diversity and that may strongly impact $\mathrm{N}$-fixer effects on ecosystem function [146].

Conceptual and mechanistic theory supports the possibility of both positive and negative effects of rhizobial diversity on legume function and legume diversity on ecosystem function, stability, and spatial heterogeneity. Although adding $\mathrm{N}$ fixers has a positive effect on many ecosystem functions $[2,22,35]$, empirical evidence for the effects of diversity within $\mathrm{N}$ fixers is mixed. Surprisingly, much of the 
empirical work discussed here shows that diversity within the legume-rhizobia mutualism often has negative effects on function at either the host-legume or ecosystem scale. However, evidence does suggest that $\mathrm{N}$-fixer diversity increases ecosystem stability and hastens the recovery of biomass and $\mathrm{N}$ cycling following disturbances [29]. Improving our understanding of the mechanisms that drive these relationships will help us predict the conditions and scales at which we expect diversity within the legume-rhizobia mutualism to either positively or negatively affect ecosystem function.

Finally, we highlight the important conclusion that causality in the BEF relationship can operate in both directions, but that the effect of ecosystem function on $\mathrm{N}$-fixer diversity remains vastly understudied. Functions such as NPP and N fixation may have important impacts on multiple scales of both legume and rhizobial diversity through a variety of potential mechanisms, but these effects remain poorly understood. Studies that experimentally stimulate changes in ecosystem function and document the effects on legume-rhizobia diversity can begin to illuminate the "other" side of the BEF relationship.

Author Contributions: Conceptualization, B.N.T and K.J.K.; writing-original draft preparation, B.N.T., E.L.S., and K.J.K.; writing—review and editing, B.N.T., E.L.S., and K.J.K.; visualization, B.N.T. and K.J.K. All authors have read and agreed to the published version of the manuscript.

Funding: B.N.T. was funded by a fellowship from the Smithsonian Institution. ELS received funding from NSF grant DEB-1457508.

Acknowledgments: The authors would like to thank two anonymous reviewers for their constructive feedback that greatly improved this work.

Conflicts of Interest: The authors declare no conflicts of interest.

\section{References}

1. Cardinale, B.J.; Srivastava, D.S.; Duffy, J.E.; Wright, J.P.; Downing, A.L.; Sankaran, M.; Jouseau, C. Effects of biodiversity on the functioning of trophic groups and ecosystems. Nature 2006, 443, 989-992. [CrossRef]

2. Hooper, D.; Chapin, F., III; Ewel, J.; Hector, A.; Inchausti, P.; Lavorel, S.; Lawton, J.; Lodge, D.; Loreau, M.; Naeem, S.; et al. Effects of biodiversity on ecosystem functioning: A concensus of current knowledge. Ecol. Monogr. 2005, 75, 3-35. [CrossRef]

3. Cardinale, B.J.; Wright, J.P.; Cadotte, M.W.; Carroll, I.T.; Hector, A.; Srivastava, D.S.; Loreau, M.; Weis, J.J. Impacts of plant diversity on biomass production increase through time because of species complementarity. Proc. Natl. Acad. Sci. USA 2007, 104, 18123-18128. [CrossRef] [PubMed]

4. Turnbull, L.A.; Levine, J.M.; Loreau, M.; Hector, A. Coexistence, niches and biodiversity effects on ecosystem functioning. Ecol. Lett. 2013, 16, 116-127. [CrossRef] [PubMed]

5. Carroll, I.T.; Cardinale, B.J.; Nisbet, R.M. Niche and fitness differences relate the maintenance of diversity to ecosystem function. Ecology 2011, 92, 1157-1165. [CrossRef] [PubMed]

6. Jain, M.; Flynn, D.F.B.; Prager, C.M.; Hart, G.M.; Devan, C.M.; Ahrestani, F.S.; Palmer, M.I.; Bunker, D.E.; Knops, J.M.H.; Jouseau, C.F.; et al. The importance of rare species: A trait-based assessment of rare species contributions to functional diversity and possible ecosystem function in tall-grass prairies. Ecol. Evol. 2014, 4, 104-112. [CrossRef] [PubMed]

7. Loreau, M.; Hector, A. Partitioning selection and complementarity in biodiversity experiments. Nature 2001, 412, 72-76. [CrossRef]

8. Weigelt, A.; Schumacher, J.; Roscher, C.; Schmid, B. Does biodiversity increase spatial stability in plant community biomass? Ecol. Lett. 2008, 11, 338-347. [CrossRef]

9. Isbell, F.I.; Polley, H.W.; Wilsey, B.J. Biodiversity, productivity and the temporal stability of productivity: Patterns and processes. Ecol. Lett. 2009, 12, 443-451. [CrossRef]

10. de Mazancourt, C.; Isbell, F.; Larocque, A.; Berendse, F.; De Luca, E.; Grace, J.B.; Haegeman, B.; Polley, H.W.; Roscher, C.; Schmid, B.; et al. Predicting ecosystem stability from community composition and biodiversity. Ecol. Lett. 2013, 16, 617-625. [CrossRef]

11. Wilcox, K.R.; Tredennick, A.T.; Koerner, S.E.; Grman, E.; Hallett, L.M.; Avolio, M.L.; La Pierre, K.J.; Houseman, G.R.; Isbell, F.; Johnson, D.S.; et al. Asynchrony among local communities stabilises ecosystem function of metacommunities. Ecol. Lett. 2017, 20, 1534-1545. [CrossRef] [PubMed] 
12. Hillebrand, H.; Matthiessen, B. Biodiversity in a complex world: consolidation and progress in function biodiversity research. Ecol. Lett. 2009, 12, 1405-1419. [CrossRef] [PubMed]

13. Lefcheck, J.S.; Byrnes, J.E.K.; Isbell, F.; Gamfeldt, L.; Griffin, J.N.; Eisenhauer, N.; Hensel, M.J.S.; Hector, A.; Cardinale, B.J.; Duffy, J.E. Biodiversity enhances ecosystem multifunctionality across trophic levels and habitats. Nat. Commun. 2015, 6, 1-7. [CrossRef] [PubMed]

14. Petchey, O.L.; Gaston, K.J. Functional diversity: Back to basics and looking forward. Ecol. Lett. 2006, 9, 741-758. [CrossRef]

15. Roscher, C.; Schumacher, J.; Gubsch, M.; Lipowsky, A.; Weigelt, A.; Buchmann, N.; Schmid, B.; Schulze, E.D. Using plant functional traits to explain diversity-productivity relationships. PLOS ONE 2012, 7, e36760. [CrossRef]

16. Sprent, J.I. The effects of water stress on nitrogen-fixing root nodules. New Phytol. 1972, 71, 443-450. [CrossRef]

17. Mylona, P.; Pawlowski, K.; Bisseling, T. Symbiotic Nitrogen Fixation. Plant Cell 1995, 7, 869-885. [CrossRef]

18. Vitousek, P.; Cassman, K.; Cleveland, C. Towards an ecological understanding of biological nitrogen fixation. Biogeochemistry 2002, 57, 1-45. [CrossRef]

19. Binkley, D.; Giardina, C. Nitrogen fixation in tropical forest plantations. ACIAR Monogr. Ser. 1997, 43, 297-337.

20. Schlesinger, W.; Bernhardt, E.S. Biogeochemistry: An Analysis Of Global Change, 3rd ed.; Elsevier: Oxford, UK, 2013.

21. Peoples, M.B.; Brockwell, J.; Herridge, D.F.; Rochester, I.J.; Alves, B.J.R.; Urquiaga, S.; Boddey, R.M.; Dakora, F.D.; Bhattarai, S.; Maskey, S.L.; et al. The contributions of nitrogen-fixing crop legumes to the productivity of agricultural systems. Symbiosis 2009, 48,1-17. [CrossRef]

22. Tilman, D.; Knops, J.; Wedin, D.; Reich, P.; Ritchie, M.; Siemann, E. The influence of functional diversity and composition on ecosystem processes. Science (80-) 1997, 277, 1300-1302. [CrossRef]

23. Vitousek, P.; Howarth, R. Nitrogen limitation on land and in the sea: how can it occur? Biogeochemistry 1991, 13, 87-115. [CrossRef]

24. Temperton, V.M.; Mwangi, P.N.; Scherer-Lorenzen, M.; Schmid, B.; Buchmann, N. Positive interactions between nitrogen-fixing legumes and four different neighbouring species in a biodiversity experiment. Oecologia 2007, 151, 190-205. [CrossRef] [PubMed]

25. Menge, D.N.L.; Chazdon, R.L. Higher survival drives the success of nitrogen-fixing trees through succession in Costa Rican rainforests. New Phytol. 2016, 209, 965-977. [CrossRef]

26. Adams, M.A.; Turnbull, T.L.; Sprent, J.I.; Buchmann, N. Legumes are different: leaf nitrogen, photosynthesis, and water use efficiency. Proc. Natl. Acad. Sci. USA 2016, 113, 4098-4113. [CrossRef]

27. Gei, M.; Rozendaal, D.M.A.; Poorter, L.; Bongers, F.; Sprent, J.I.; Garner, M.D.; Aide, T.M.; Andrade, J.L.; Balvanera, P.; Becknell, J.M.; et al. Legume abundance along successional and rainfall gradients in Neotropical forests. Nat. Ecol. Evol. 2018, 2, 1104-1111. [CrossRef]

28. Pellegrini, A.F.A.; Staver, A.C.; Hedin, L.O.; Charles-Dominique, T.; Tourgee, A. Aridity, not fire, favors nitrogen-fixing plants across tropical savanna and forest biomes. Ecology 2016, 97, 2177-2183. [CrossRef]

29. Batterman, S.A.; Hedin, L.O.; van Breugel, M.; Ransijn, J.; Craven, D.J.; Hall, J.S. Key role of symbiotic dinitrogen fixation in tropical forest secondary succession. Nature 2013, 502, 224-227. [CrossRef]

30. Vitousek, P.M.; Walker, L.R. Colonization, succession, and resource availability: Ecosystem-level interactions. In Colonization, Succession, and Stability; Gray, A., Crawley, M., Edwards, P., Eds.; Blackwell Scientific: Oxford, UK, 1987; pp. 207-223.

31. Sprent, J.I.; Sutherland, J.; de Faria, S. Some aspects of the biology of nitrogen-fixing organisms. Philos. Trans. R. Soc. Lond. B Biol. Sci. 1987, 317, 111-129.

32. Oono, R.; Schmitt, I.; Sprent, J.I.; Denison, R.F. Multiple evolutionary origins of legume traits leading to extreme rhizobial differentiation. New Phytol. 2010, 187, 508-520. [CrossRef]

33. Werner, G.D.A.; Cornwell, W.K.; Sprent, J.I.; Kattge, J.; Kiers, E.T. A single evolutionary innovation drives the deep evolution of symbiotic $\mathrm{N}_{2}$-fixation in angiosperms. Nat. Commun. 2014, 5, 1-9. [CrossRef] [PubMed]

34. Tilman, D. Constraints and tradeoffs: toward a predictive theory of competition and succession. Oikos 1990, 58, 3-15. [CrossRef] 
35. Flynn, D.F.B.; Mirotchnick, N.; Jain, M.; Palmer, M.I.; Naeem, S. Functional and phylogenetic diversity as predictors of biodiversity- Ecosystem-function relationships. Ecology 2011, 92, 1573-1581. [CrossRef] [PubMed]

36. Spehn, E.M.; Scherer-Lorenzen, M.; Schmid, B.; Hector, A.; Caldeira, M.C.; Dimitrakopoulos, P.G.; Finn, J.A.; Jumpponen, A.; O'Donnovan, G.; Pereira, J.S.; et al. The role of legumes as a component of biodiversity in a cross-European study of grassland biomass nitrogen. Oikos 2002, 98, 205-218. [CrossRef]

37. Eisenhauer, N. Aboveground-belowground interactions as a source of complementarity effects in biodiversity experiments. Plant Soil 2012, 351, 1-22. [CrossRef]

38. Huss-Danell, K. Actinorhizal symbioses and their N2 fixation. New Phytol. 1997, 136, 375-405. [CrossRef]

39. Santi, C.; Bogusz, D.; Franche, C. Biological nitrogen fixation in non-legume plants. Ann. Bot. 2013, 111, 743-767. [CrossRef]

40. de Lajudie, P.M.; Andrews, M.; Ardley, J.; Eardly, B.; Jumas-Bilak, E.; Kuzmanović, N.; Lassalle, F.; Lindström, K.; Mhamdi, R.; Martínez-Romero, E.; et al. Minimal standards for the description of new genera and species of rhizobia and agrobacteria. Int. J. Syst. Evol. Microbiol. 2019, 69, 1852-1863. [CrossRef]

41. Doyle, J.J.; Luckow, M.A. The rest of the iceberg. Legume diversity and evolution in a phylogenetic context. Plant Physiol. 2003, 131, 900-910. [CrossRef]

42. Azani, N.; Babineau, M.; Bailey, C.D.; Banks, H.; Barbosa, A.R.; Pinto, R.B.; Boatwright, J.S.; Borges, L.M.; Brown, G.K.; Bruneau, A.; et al. A new subfamily classification of the leguminosae based on a taxonomically comprehensive phylogeny. Taxon 2017, 66, 44-77. [CrossRef]

43. Sprent, J.; Ardley, J.; James, E.K. Biogeography of nodulated legumes and their nitrogen fixing symbionts. New Phytol. 2017, 215, 40-56. [CrossRef] [PubMed]

44. Siefert, A.; Zillig, K.W.; Friesen, M.L.; Strauss, S.Y. Mutualists stabilize the coexistence of congeneric legumes. Am. Nat. 2019, 193, 200-212. [CrossRef] [PubMed]

45. Van Der Heijden, M.G.A.; Bakker, R.; Verwaal, J.; Scheublin, T.R.; Rutten, M.; Van Logtestijn, R.; Staehelin, C. Symbiotic bacteria as a determinant of plant community structure and plant productivity in dune grassland. FEMS Microbiol. Ecol. 2006, 56, 178-187. [CrossRef] [PubMed]

46. De Queiroz, K. Species concepts and species delimitation. Syst. Biol. 2007, 56, 879-886. [CrossRef] [PubMed]

47. Sprent, J.I. Evolving ideas of legume evolution and diversity: A taxonomic perspective on the occurrence of nodulation. New Phytol. 2007, 174, 11-25. [CrossRef]

48. Bailly, X.; Giuntini, E.; Sexton, M.C.; Lower, R.P.J.; Harrison, P.W.; Kumar, N.; Young, J.P.W. Population genomics of Sinorhizobium medicae based on low-coverage sequencing of sympatric isolates. ISME J. 2011, 5, 1722-1734. [CrossRef]

49. González, V.; Santamaría, R.I.; Bustos, P.; Pérez-Carrascal, O.M.; Vinuesa, P.; Juárez, S.; Martínez-Flores, I.; Cevallos, M.Á.; Brom, S.; Martínez-Romero, E.; et al. Phylogenomic Rhizobium species are structured by a continuum of diversity and genomic clusters. Front. Microbiol. 2019, 10, 1-15. [CrossRef] [PubMed]

50. Kumar, N.; Lad, G.; Giuntini, E.; Kaye, M.E.; Udomwong, P.; Jannah Shamsani, N.; Peter W Young, J.; Bailly, X. Bacterial genospecies that are not ecologically coherent: Population genomics of rhizobium leguminosarum. Open Biol. 2015, 5, 140133. [CrossRef]

51. Wielbo, J. Rhizobial communities in symbiosis with legumes: Genetic diversity, competition and interactions with host plants. Cent. Eur. J. Biol. 2012, 7, 363-372. [CrossRef]

52. Willems, A. The taxonomy of rhizobia: An overview. Plant Soil 2006, 287, 3-14. [CrossRef]

53. Aoki, S.; Ito, M.; Iwasaki, W. From $\beta$ - To $\alpha$-proteobacteria: The origin and evolution of rhizobial nodulation genes nodij. Mol. Biol. Evol. 2013, 30, 2494-2508. [CrossRef] [PubMed]

54. Harrison, S.P.; Jones, D.G.; Young, J.P.W. Rhizobium population genetics: Genetic variation within and between populations from diverse locations. Microbiology 1989, 135, 1061-1069. [CrossRef]

55. Dresler-Nurmi, A.; Fewer, D.; Rasanen, L.; Lindstrom, K. The diversity and evolution of rhizobia. In Prokaryotic Symbionts in Plants; Pawlowski, K., Ed.; Springer-Verlag: Berlin/Heidelberg, Germany, 2009; pp. 3-41.

56. Young, J.; Haukka, K. Diversity and phylogeny of rhizobia. New Phytol. 1996, 133, 87-94.

57. Siler, E.; Friesen, M.L. Widespread negative frequency-dependent selection maintains diversity in the legume-rhizobia symbiosis: Balancing nodulation may explain the paradox of rhizobium diversity. bioRxiv 2017. [CrossRef]

58. La Pierre, K.J.; Simms, E.L.; Tariq, M.; Zafar, M.; Porter, S.S. Invasive legumes can associate with many mutualists of native legumes, but usually do not. Ecol. Evol. 2017, 7, 8599-8611. [CrossRef] 
59. Keet, J.H.; Ellis, A.G.; Hui, C.; Le Roux, J.J. Legume-rhizobium symbiotic promiscuity and effectiveness do not affect plant invasiveness. Ann. Bot. 2017, 119, 1319-1331. [CrossRef]

60. Jiao, Y.S.; Liu, Y.H.; Yan, H.; Wang, E.T.; Tian, C.F.; Chen, W.X.; Guo, B.L.; Chen, W.F. Rhizobial diversity and nodulation characteristics of the extremely promiscuous legume Sophora flavescens. Mol. Plant-Microbe Interact. 2015, 28, 1338-1352. [CrossRef]

61. Simms, E.L.; Taylor, D.L. Partner choice in nitrogen-fixation mutualisms of legumes and rhizobia. Integr. Comp. Biol. 2002, 42, 369-380. [CrossRef]

62. Marquard, E.; Weigelt, A.; Temperton, V.M.; Roscher, C.; Schumacher, J.; Buchmann, N.; Fischer, M.; Weisser, W.W.; Schmid, B. Plant species richness and functional composition drive overyielding in a six-year grassland experiment. Ecology 2009, 90, 3290-3302. [CrossRef]

63. Menge, D.N.L.; Wolf, A.A.; Funk, J.L. Diversity of nitrogen fixation strategies in Mediterranean legumes. Nat. Plants 2015, 1, 15064. [CrossRef]

64. Batterman, S.A.; Wurzburger, N.; Hedin, L.O. Nitrogen and phosphorus interact to control tropical symbiotic $\mathrm{N}_{2}$ fixation: A test in Inga punctata. J. Ecol. 2013, 101, 1400-1408. [CrossRef]

65. Taylor, B.N.; Menge, D.N.L. Light regulates tropical symbiotic nitrogen fixation more strongly than soil nitrogen. Nat. Plants 2018, 4, 655-661. [CrossRef] [PubMed]

66. Myster, R.W. Light and nutrient effects on growth and allocation of Inga vera (Leguminosae), a successional tree of Puerto Rico. Can. J. For. Res. 2006, 36, 1121-1128. [CrossRef]

67. Wurzburger, N.; Miniat, C.F. Drought enhances symbiotic dinitrogen fixation and competitive ability of a temperate forest tree. Oecologia 2014, 174, 1117-1126. [CrossRef]

68. Dovrat, G.; Masci, T.; Bakhshian, H.; Mayzlish Gati, E.; Golan, S.; Sheffer, E. Drought-adapted plants dramatically downregulate dinitrogen fixation: Evidences from Mediterranean legume shrubs. J. Ecol. 2018, 106, 1534-1544. [CrossRef]

69. Dovrat, G.; Sheffer, E. Symbiotic dinitrogen fixation is seasonal and strongly regulated in water-limited environments. New Phytol. 2019, 221, 1866-1877. [CrossRef]

70. Crews, T.E. Phosphorus regulation of nitrogen fixation in a traditional Mexican agroecosystem. Biogeochemistry 1993, 21, 141-166. [CrossRef]

71. Wilcots, M.E.; Menge, D.N.L.; Kuprewicz, E.K.; Taylor, B.N. Small traits with big consequences: How seed traits of nitrogen-fixing plants might influence ecosystem nutrient cycling. Oikos 2019, 128, 668-679. [CrossRef]

72. Reid, D.E.; Ferguson, B.J.; Hayashi, S.; Lin, Y.H.; Gresshoff, P.M. Molecular mechanisms controlling legume autoregulation of nodulation. Ann. Bot. 2011, 108, 789-795. [CrossRef]

73. Kiers, E.T.; Rousseau, R.A.; West, S.A.; Denison, R.F. Host sanctions and the legume-rhizobium mutualism. Nature 2003, 425, 78-81. [CrossRef]

74. Menge, D.N.L.; Levin, S.A.; Hedin, L.O. Facultative versus obligate nitrogen fixation strategies and their ecosystem consequences. Am. Nat. 2009, 174, 465-477. [CrossRef] [PubMed]

75. Binkley, D.; Cromack, K.; Backer, D.D. Nitrogen fixation by red alder: Biology, rates, and controls. In The Biology and Managment of Red Alder; Hibbs, D., Tarrant, R., DeBell, D., Eds.; Oregon State University Press: Corvalis, OR, USA, 1994; pp. 57-72.

76. Roscher, C.; Thein, S.; Weigelt, A.; Temperton, V.M.; Buchmann, N.; Schulze, E.D. $\mathrm{N}_{2}$ fixation and performance of 12 legume species in a 6-year grassland biodiversity experiment. Plant Soil 2011, 341, 333-348. [CrossRef]

77. West, J.B.; HilleRisLambers, J.; Lee, T.D.; Hobbie, S.E.; Reich, P.B. Legume species identity and soil nitrogen supply determine symbiotic nitrogen-fixation responses to elevated atmospheric $\left[\mathrm{CO}_{2}\right]$. New Phytol. 2005, 167, 523-530. [CrossRef]

78. Hagen, M.; Hamrick, J. A hierarchical analysis of population genetic structure in Rhizobium leguminosarum bv. trifolii. Mol. Ecol. 1996, 5, 177-186. [CrossRef] [PubMed]

79. Klock, M.M.; Barrett, L.G.; Thrall, P.H.; Harms, K.E. Host promiscuity in symbiont associations can influence exotic legume establishment and colonization of novel ranges. Divers. Distrib. 2015, 21, 1193-1203. [CrossRef]

80. Futuyma, D.J.; Moreno, G. The evolution of ecological specialization. Annu. Rev. Ecol. Syst. 1988, 19, $207-233$. [CrossRef]

81. Wilson, D.S.; Yoshimura, J. On the coexistence of specialists and generalists. Am. Nat. 1994, 144, 692-707. [CrossRef] 
82. Ehinger, M.; Mohr, T.J.; Starcevich, J.B.; Sachs, J.L.; Porter, S.S.; Simms, E.L. Specialization-generalization trade-off in a Bradyrhizobium symbiosis with wild legume hosts. BMC Ecol. 2014, 14, 1-18. [CrossRef]

83. Devine, T.E.; Kuykendall, L.D. Host genetic control of symbiosis in soybean (Glycine max L.). Plant Soil 1996, 186, 173-187. [CrossRef]

84. Materon, L.; Zibilske, L. Delayed inoculation and competition of nitrogen-fixing strains in Medicago noeana (Boiss.) and Medicago polymorpha (L.). Appl. Soil Ecol. 2001, 17, 175-181. [CrossRef]

85. Oono, R.; Denison, R.F.; Kiers, E.T. Controlling the reproductive fate of rhizobia: How universal are legume sanctions? New Phytol. 2009, 183, 967-979. [CrossRef] [PubMed]

86. Kiers, E.T.; Denison, R.F. Sanctions, cooperation, and the stability of plant-rhizosphere mutualisms. Annu. Rev. Ecol. Evol. Syst. 2008, 39, 215-236. [CrossRef]

87. West, S.A.; Kiers, E.T.; Simms, E.L.; Denison, R.F. Sanctions and mutualism stability: Why do rhizobia fix nitrogen? Proc. R. Soc. B Biol. Sci. 2002, 269, 685-694. [CrossRef]

88. Bever, J.D.; Broadhurst, L.M.; Thrall, P.H. Microbial phylotype composition and diversity predicts plant productivity and plant-soil feedbacks. Ecol. Lett. 2013, 16, 167-174. [CrossRef]

89. Thrall, P.H.; Slattery, J.F.; Broadhurst, L.M.; Bickford, S. Geographic patterns of symbiont abundance and adaptation in native Australian Acacia-rhizobia interactions. J. Ecol. 2007, 95, 1110-1122. [CrossRef]

90. Finan, T.M. Evolving insights: Symbiosis islands and horizontal gene transfer. J. Bacteriol. 2002, 184, 2855-2856. [CrossRef] [PubMed]

91. MacLean, A.M.; Finan, T.M.; Sadowsky, M.J. Genomes of the symbiotic nitrogen-fixing bacteria of legumes. Plant Physiol. 2007, 144, 615-622. [CrossRef] [PubMed]

92. Peix, A.; Ramírez-Bahena, M.H.; Velázquez, E.; Bedmar, E.J. Bacterial associations with legumes. CRC. Crit. Rev. Plant Sci. 2015, 34, 17-42. [CrossRef]

93. Drew, E.A.; Charman, N.; Dingemanse, R.; Hall, E.; Ballard, R.A. Symbiotic performance of Mediterranean Trifolium spp. with naturalised soil rhizobia. Crop Pasture Sci. 2011, 62, 903-913. [CrossRef]

94. Lammel, D.R.; Cruz, L.M.; Carrer, H.; Cardoso, E.J.B.N. Diversity and symbiotic effectiveness of beta-rhizobia isolated from sub-tropical legumes of a Brazilian Araucaria forest. World J. Microbiol. Biotechnol. 2013, 29, 2335-2342. [CrossRef]

95. Sachs, J.L.; Kembel, S.W.; Lau, A.H.; Simms, E.L. In situ phylogenetic structure and diversity of wild Bradyrhizobium communities. Appl. Environ. Microbiol. 2009, 75, 4727-4735. [CrossRef] [PubMed]

96. Perret, X.; Staehelin, C.; Broughton, W.J. Molecular Basis of Symbiotic Promiscuity. Microbiol. Mol. Biol. Rev. 2000, 64, 180-201. [CrossRef] [PubMed]

97. Barrett, L.G.; Bever, J.D.; Bissett, A.; Thrall, P.H. Partner diversity and identity impacts on plant productivity in Acacia-rhizobial interactions. J. Ecol. 2015, 103, 130-142. [CrossRef]

98. Kaschuk, G.; Leffelaar, P.A.; Giller, K.E.; Alberton, O.; Hungria, M.; Kuyper, T.W. Responses of legumes to rhizobia and arbuscular mycorrhizal fungi: A meta-analysis of potential photosynthate limitation of symbioses. Soil Biol. Biochem. 2010, 42, 125-127. [CrossRef]

99. Fox, J.W. Interpreting the "selection effect" of biodiversity on ecosystem function. Ecol. Lett. 2005, 8, 846-856. [CrossRef]

100. Lechevalier, M.; Lechevalier, H. Systematics, isolation, and culture of Frankia. In The Biology of Frankia and Actinorhizal Plants; Schwintzer, C.R., Tjepkema, J.D., Eds.; Academic Press: San Diego, CA, USA, 1990; pp. 35-56.

101. Friesen, M.L.; Mathias, A. Mixed infections may promote diversification of mutualistic symbionts: Why are there ineffective rhizobia? J. Evol. Biol. 2010, 23, 323-334. [CrossRef]

102. Clark, T.J.; Friel, C.A.; Grman, E.; Friesen, M.L.; Shachar-Hill, Y. Unfair trade underground revealed by integrating data with Nash bargaining models. New Phytol. 2019, 222, 1325-1337. [CrossRef]

103. Friesen, M.L. Widespread fitness alignment in the legume-Rhizobium symbiosis. New Phytol. 2012, 194, 1096-1111. [CrossRef]

104. Goel, A.K.; Sindhu, S.S.; Dadarwal, K.R. Symbiotic effectiveness of bacteriocin producing and non-producing strains of Rhizobium in green gram (Vigna radiata). Indian J. Exp. Biol. 2001, 39, 821-823.

105. Bala, A.; Giller, K.E. Relationships between rhizobial diversity and host legume nodulation and nitrogen fixation in tropical ecosystems. Nutr. Cycl. Agroecosystems 2006, 76, 319-330. [CrossRef]

106. Lambers, J.H.R.; Harpole, W.S.; Tilman, D.; Knops, J.; Reich, P.B. Mechanisms responsible for the positive diversity-productivity relationship in Minnesota grasslands. Ecol. Lett. 2004, 7, 661-668. [CrossRef] 
107. Fargione, J.; Tilman, D.; Dybzinski, R.; Lambers, J.H.R.; Clark, C.; Harpole, W.S.; Knops, J.M.H.; Reich, P.B.; Loreau, M. From selection to complementarity: Shifts in the causes of biodiversity-productivity relationships in a long-term biodiversity experiment. Proc. R. Soc. B Biol. Sci. 2007, 274, 871-876. [CrossRef] [PubMed]

108. Mulder, C.P.H.; Jumpponen, A.; Högberg, P.; Huss-Danell, K. How plant diversity and legumes affect nitrogen dynamics in experimental grassland communities. Oecologia 2002, 133, 412-421. [CrossRef] [PubMed]

109. Lee, T.D.; Reich, P.B.; Tjoelker, M.G. Legume presence increases photosynthesis and N concentrations of co-occurring non-fixers but does not modulate their responsiveness to carbon dioxide enrichment. Oecologia 2003, 137, 22-31. [CrossRef]

110. Spehn, E.M.; Hector, A.; Joshi, J.; Scherer-Lorenzen, M.; Schmid, B.; Bazeley-White, E.; Beierkuhnlein, C.; Caldeira, M.C.; Diemer, M.; Dimitrakopoulos, P.G.; et al. Ecosystem effects of biodiversity manipulations in european grasslands. Ecol. Monogr. 2005, 75, 37-63. [CrossRef]

111. Whittaker, R.H. Vegetation of the Siskiyou mountains, Oregon and California. Ecol. Monogr. 1960, 30, 279-338. [CrossRef]

112. Grünzweig, J.M.; Körner, C. Growth, water and nitrogen relations in grassland model ecosystems of the semi-arid Negev of Israel exposed to elevated $\mathrm{CO}_{2}$. Oecologia 2001, 128, 251-262. [CrossRef]

113. Ferreira da Silva, A.; Santiago de Freitas, A.D.; Costa, T.L.; Fernandes-Junior, P.I.; Martins, L.M.V.; de Rosalia e Silva Santos, C.E.; Menezes, K.A.S.; de Sa Barretto Sampaio, E.V. Biological nitrogen fixation in tropical dry forests with different legume diversity and abundance. Nutr. Cycl. Agroecosystems 2017, 107, 321-334. [CrossRef]

114. Levine, J.M.; HilleRisLambers, J. The importance of niches for the maintenance of species diversity. Nature 2009, 461, 254-257. [CrossRef]

115. Turnbull, L.A.; Rahm, S.; Baudois, O.; Eichenberger-Glinz, S.; Wacker, L.; Schmid, B. Experimental invasion by legumes reveals non-random assembly rules in grassland communities. J. Ecol. 2005, 93, 1062-1070. [CrossRef]

116. Kéfi, S.; Domínguez-García, V.; Donohue, I.; Fontaine, C.; Thébault, E.; Dakos, V. Advancing our understanding of ecological stability. Ecol. Lett. 2019, 1349-1356. [CrossRef] [PubMed]

117. Donohue, I.; Hillebrand, H.; Montoya, J.M.; Petchey, O.L.; Pimm, S.L.; Fowler, M.S.; Healy, K.; Jackson, A.L.; Lurgi, M.; McClean, D.; et al. Navigating the complexity of ecological stability. Ecol. Lett. 2016, 19, 1172-1185. [CrossRef] [PubMed]

118. Menge, D.N.L.; Levin, S.A. Spatial heterogeneity can resolve the nitrogen paradox of tropical forests. Ecology 2017, 98, 1049-1061. [CrossRef] [PubMed]

119. Menge, D.; Hedin, L. Nitrogen fixation in different biogeochemical niches along a 120,000 -year chronosequence in New Zealand. Ecology 2009, 90, 2190-2201. [CrossRef] [PubMed]

120. Boring, L.; Swank, W. The role of black locust (Robinia pseudo-acacia) in forest succession. J. Ecol. 1984, 72, 749-766. [CrossRef]

121. Chapin, F.S., III; Walker, L.; Fastie, C.; Sharman, L. Mechanisms of primary succession following deglaciation at Glacier Bay, Alaska. Ecol. Monogr. 1994, 64, 149-175. [CrossRef]

122. Oliver, T.H.; Heard, M.; Isaac, N.; Roy, D.; Procter, D.; Eigenbrod, F.; Freckleton, R.; Hector, A.; Orme, C.; Petchey, O.; et al. Biodiversity and resilience of ecosystem functions. Trends Ecol. Evol. 2015, 30, 673-684. [CrossRef]

123. Tilman, D.; Reich, P.B.; Knops, J.M.H. Biodiversity and ecosystem stability in a decade-long grassland experiment. Nature 2006, 441, 629-632. [CrossRef]

124. Denison, R.F.; Kiers, E.T. Life histories of symbiotic rhizobia and mycorrhizal fungi. Curr. Biol. 2011, 21, R775-R785. [CrossRef]

125. McKey, D. Legumes and nitrogen: The evolutionary ecology of a nitrogen-demanding lifestyle. In Advances in Legume Systematics 5: The Nitrogen Factor; Sprent, J., McKey, D., Eds.; Royal Botanic Gardens: Kew, UK, 1994; pp. 211-228.

126. Menge, D.N.L.; Batterman, S.A.; Liao, W.; Taylor, B.N.; Lichstein, J.W.; Ángeles-Pérez, G. Nitrogen-fixing tree abundance in higher-latitude North America is not constrained by diversity. Ecol. Lett. 2017, 20, 842-851. [CrossRef]

127. Poorter, L.; Bongers, F.; Aide, T.M.; Almeyda Zambrano, A.M.; Balvanera, P.; Becknell, J.M.; Boukili, V.; Brancalion, P.H.S.; Broadbent, E.N.; Chazdon, R.L.; et al. Biomass resilience of Neotropical secondary forests. Nature 2016, 530, 211-214. [CrossRef] [PubMed] 
128. Taylor, B.N.; Chazdon, R.L.; Menge, D.N.L. Successional dynamics of nitrogen fixation and forest growth in regenerating Costa Rican rainforests. Ecology 2019, 100, e02637. [CrossRef] [PubMed]

129. Kiers, E.T.; Rousseau, R.A.; Denison, R.F. Measured sanctions: Legume hosts detect quantitative variation in rhizobium cooperation and punish accordingly. Evol. Ecol. Res. 2006, 8, 1077-1086.

130. King, B.J.; Layzell, D.B. Effect of increases in oxygen concentration during the argon-induced decline in nitrogenase activity in root nodules of soybean. Plant Physiol. 1991, 96, 376-381. [CrossRef] [PubMed]

131. Wårlind, D.; Smith, B.; Hickler, T.; Arneth, A. Nitrogen feedbacks increase future terrestrial ecosystem carbon uptake in an individual-based dynamic vegetation model. Biogeosciences 2014, 11, 151-185. [CrossRef]

132. Peng, J.; Wang, Y.-P.; Houlton, B.Z.; Dan, L.; Pak, B.; Tang, X. Global carbon sequestration is highly sensitive to model-based formulations of nitrogen fixation. Glob. Biogeochem. Cycles 2019. [CrossRef]

133. Gerber, S.; Hedin, L.O.; Keel, S.G.; Pacala, S.W.; Shevliakova, E. Land use change and nitrogen feedbacks constrain the trajectory of the land carbon sink. Geophys. Res. Lett. 2013, 40, 5218-5222. [CrossRef]

134. Akçay, E.; Roughgarden, J. Negotiation of mutualism: Rhizobia and legumes. Proc. R. Soc. B Biol. Sci. 2007, 274, 25-32. [CrossRef]

135. Trierweiler, A.M.; Winter, K.; Hedin, L.O. Rising $\mathrm{CO}_{2}$ accelerates phosphorus and molybdenum limitation of $\mathrm{N}_{2}$-fixation in young tropical trees. Plant Soil 2018, 429, 363-373. [CrossRef]

136. Weese, D.J.; Heath, K.D.; Dentinger, B.T.M.; Lau, J.A. Long-term nitrogen addition causes the evolution of less-cooperative mutualists. Evolution (N. Y.) 2015, 69, 631-642. [CrossRef]

137. Houlton, B.Z.; Wang, Y.-P.; Vitousek, P.M.; Field, C.B. A unifying framework for dinitrogen fixation in the terrestrial biosphere. Nature 2008, 454, 327-330. [CrossRef] [PubMed]

138. Liao, W.; Menge, D.N.L.; Lichstein, J.W.; Ángeles-Pérez, G. Global climate change will increase the abundance of symbiotic nitrogen-fixing trees in much of North America. Glob. Chang. Biol. 2017, 23, 4777-4787. [CrossRef] [PubMed]

139. Hayman, D. Mycorrhizae of nitrogen-fixing legumes. Mircen J. Appl. Microbiol. Biotechnol. 1986, 2, 121-145. [CrossRef]

140. Smith, S.; Nicholas, D.; Smith, F. Effect of early mycorrhizal infection on nodulation and nitrogen fixation in Trifolium subterraneum L. Funct. Plant Biol. 1979, 6, 305. [CrossRef]

141. Diagne, N.; Thioulouse, J.; Sanguin, H.; Prin, Y.; Krasova-Wade, T.; Sylla, S.; Galiana, A.; Baudoin, E.; Neyra, M.; Svistoonoff, S.; et al. Ectomycorrhizal diversity enhances growth and nitrogen fixation of Acacia mangium seedlings. Soil Biol. Biochem. 2013, 57, 468-476. [CrossRef]

142. Nasto, M.K.; Alvarez-Clare, S.; Lekberg, Y.; Sullivan, B.W.; Townsend, A.R.; Cleveland, C.C. Interactions among nitrogen fixation and soil phosphorus acquisition strategies in lowland tropical rain forests. Ecol. Lett. 2014, 17, 1282-1289. [CrossRef]

143. Mayer, V.E.; Frederickson, M.E.; Mckey, D.; Blatrix, R. Current issues in the evolutionary ecology of ant-plant symbioses. New Phytol. 2014, 202, 749-764. [CrossRef]

144. Tarnita, C.E.; Palmer, T.M.; Pringle, R.M. Colonisation and competition dynamics can explain incomplete sterilisation parasitism in ant-plant symbioses. Ecol. Lett. 2014, 17, 1290-1298. [CrossRef]

145. Godschalx, A.L.; Schadler, M.; Trisel, J.; Balkan, M.; Ballhorn, D. Ants are less attracted to the extrafloral nectar of plants with symbiotic, nitrogen-fixing rhizobia. Ecology 2015, 96, 348-354. [CrossRef]

146. Afkhami, M.E.; Rudgers, J.A.; Stachowicz, J.J. Multiple mutualist effects: Conflict and synergy in multispecies mutualisms. Ecology 2014, 95, 833-844. [CrossRef]

(C) 2020 by the authors. Licensee MDPI, Basel, Switzerland. This article is an open access article distributed under the terms and conditions of the Creative Commons Attribution (CC BY) license (http://creativecommons.org/licenses/by/4.0/). 